\title{
PERBEDAAN PROFIL LIPID PASIEN STROKE ISKEMIK DAN STROKE HEMORAGIK DI RSUD MEURAXA KOTA BANDA ACEH
}

\author{
Selvirawati ${ }^{1}$, Abdul Wahab ${ }^{2}$, Rizarullah ${ }^{2}$ \\ ${ }^{1}$ Program Studi Kedokteran, Fakultas Kedokteran, Universitas Abulyatama \\ ${ }^{2}$ Dosen Program Studi Pendidikan Dokter
}

[Email korespondensi: selviraselv@gmail.com]

\begin{abstract}
Differences in Lipid Profiles of Ischemic Stroke and Hemorrhagic Stroke Patients in Meuraxa Hospital, Banda Aceh City. Stroke is a cerebrovascular disease characterized by the death of brain tissue (cerebral infarction) that occurs due to reduced blood flow to the brain. Strokes generally cause serious damage or necrosis of brain tissue. One risk factor for stroke is dyslipidemia. This study aims to determine differences in lipid profiles in patients with ischemic stroke and hemorrhagic stroke. The design used in this study was a cross sectional study that used secondary data from stroke patients from the medical records of Meuraxa Hospital in Banda Aceh. Data analysis uses the Independent sample $t$ test if the data is distributed. Whereas if the data are not distributed normally, the non-parametric Mann-Whitney $U$ test is used as an alternative method. Data normality testing is done by the Shapiro-Wilk test method. This study focuses on ischemic and hemorrhagic stroke patients aged 5070 years from January to December 2019. The number of samples used was 56 stroke patients consisting of 30 ischemic stroke patients and 26 hemorrhagic stroke patients. The results of this study show the $p$ values for total cholesterol, $L D L, H D L$, and triglycerides, respectively $0.013,0.271,0.040$, and 0.421 . There are differences in lipid profiles in patients with ischemic stroke and hemorrhagic stroke.
\end{abstract}

Keywords: Ischemic Stroke, Hemorrhagic Stroke, Cholesterol Levels

\begin{abstract}
Abstrak: Perbedaan Profil Lipid Pasien Stroke Iskemik dan Stroke Hemoragik di RSUD Meuraxa Kota Banda Aceh. Stroke termasuk penyakit serebrovaskular yang ditandai dengan kematian jaringan otak (infark serebral) yang terjadi karena berkurangnya aliran darah ke otak. Serangan stroke umumnya menyebakan kerusakan yang serius atau nekrosis pada jaringan otak. Salah satu faktor risiko stroke adalah dislipidemia. Penelitian ini bertujuan untuk mengetahui perbedaan profil lipid pada pasien stroke iskemik dan stroke hemoragik. Desain yang digunakan dalam peneitian ini adalah studi potong lintang (Cross Sectional) yang menggunakan data sekunder pasien stroke dari catatan rekam medik RSUD Meuraxa Banda Aceh. Analisis data menggunakan Uji T-test sampel tidak berpasangan (Independent sample $t$ test) dan uji non-parametrik Mann-Whitney $U$ test. Pengujian normalitas data dilakukan dengan metode Shapiro-Wilk test. Penelitian ini berfokus pada pasien stroke iskemik dan stroke hemoragik rentang usia 50-70 tahun periode Januari-Desember 2019. Jumlah sampel yang digunakan 56 pasien stroke yang terdiri dari 30 pasien stroke iskemik dan 26 pasien stroke hemoragik. Hasil penelitian ini menunjukan nilai p untuk kolesterol total, LDL, HDL, dan trigliserida, berturut-turut $0,013,0,271,0,040$, dan 0,421 . Terdapat perbedaan profil lipid pada pasien stroke iskemik dan stroke hemoragik
\end{abstract}

Kata kunci: Stroke Iskemik, Stroke Hemoragik, Kadar Kolesterol 


\section{PENDAHULUAN}

Menurut WHO (2016) stroke merupakan penyebab kematian kedua dan penyebab kecacatan ketiga di dunia. Stroke dapat diartikan sebagai kematian mendadak beberapa sel otak karena kekurangan oksigen ketika darah mengalir ke otak yang diakibatkan oleh penyumbatan atau pecahnya pembuluh darah ke otak. Secara global, stroke merupakan penyebab dari $70 \%$ kematian dan $87 \%$ penyebab kecacatan di negara berkembang. Penyakit jantung dan stroke membunuh 17 juta orang per tahun, hampir sepertiga dari semua kematian secara global. Diperkirakan pada tahun 2020 , penyakit jantung dan stroke akan meningkat lebih dari 20 jita jiwa per tahun dan pada tahun 2030 menjadi lebih dari 24 juta jiwa (WHO, 2014).

Berdasarkan data Kementrian Kesehatan Republik Indonesia tahun 2019, pada tahun 1990 angka kejadian penyakit tidak menular sebanyak $39.81 \%$ dan meningkat menjadi $69,9 \%$ pada tahun 2017 (Badan Penelitian dan Pengembangan Kesehatan, 2019). Buku Epidemiologi Penyakit Tidak Menular menuliskan bahwa yang tergolong ke dalam PTM antara lain adalah; Penyakit kardiovaskuler (jantung, aterosklerosis, hipertensi, penyakit jantung koroner dan stroke), diabetes melitus serta kanker (Irwan, 2018). Salah satu penyakit tidak menular yang sampai saat ini masih menjadi masalah global adalah stroke. Stroke menempati peringkat teratas dari 10 penyebab kematian tahun 1990 dan 2017 di Indonesia (Badan Penelitian dan Pengembangan Kesehatan, 2019). Stroke juga menempati peringkat pertama untuk sepuluh peringkat teratas DALY Lost Tahun 2017 di Indonesia. Jumlah penderita stroke terus mengalami peningkatan setiap tahunnya. Menurut Yayasan Stroke Indonesia, setiap tahun diperkirakan 500.000 penduduk mengalami serangan stroke dan $25 \%$ diantaranya (125.000 penduduk) meninggal, sisanya mengalami disabilitas ringan maupun berat jangka panjang (Yayasan Stroke Indonesia, 2013).

Stroke yang juga dikenal dengan istilah cerebrovascular accident atau brain attack merupakan kerusakan mendadak pada peredaran darah otak dalam satu pembuluh darah arteri atau lebih. Serangan stroke akan mengganggu atau mengurangi pasokan oksigen dan umumnya menyebakan kerusakan yang serius atau nekrosis pada jaringan otak (Kowalak and Jenifer $P$, 2017).

Berdasarkan kelainan patologis yang terjadi, stroke terbagi menjadi 2 golongan major yaitu stroke iskemik dan stroke hemoragik. Stroke iskemik terjadi ketika suplai darah ke beberapa bagian di otak tidak mencukupi karena adanya oklusi pembuluh darah arteri otak sehingga terjadi iskemia dan oksigen yang dibutuhkan oleh sel otak menjadi sedikit atau bahkan tidak ada (Yunadi, 2012). Stroke hemoragik terjadi apabila adanya perdarahan akibat pecahnya pembuluh darah di otak sehingga menyebabkan kerusakan otak dan gangguan fungsi saraf. Stroke jenis hemoragik ini paling bahaya karena dapat menimbulkan kerusakan yang luas akibat genangan darah di otak (Wahyuddin and Arief W, 2018). Sekitar $83 \%$ dari seluruh kejadian stroke berupa stroke iskemik dengan mekanisme berbeda yaitu 30\% disebakan karena trombosis arteri besar, kurang dari $5 \%$ stroke disebabkan oleh trombosis arteri sedang, sedangkan $20 \%$ stroke disebakan trombosis cabang-cabang arteri kecil pada korteks serebri. Kurang dari $32 \%$ disebabkan oleh emboli, yaitu tersumbatnya arteri oleh bekuan darah yang berasal dari tempat lain di sirkulasi. Angka kejadian stroke hemoragik yaitu sekitar $20 \%$ dari seluruh kejadian stroke. Salah satu dari sekian banyak faktor risiko stroke adalah dislipidemia.

Dislipidemia merupakan kelainan metabolisme lipid yang ditandai dengan 
peningkatan maupun penurunan fraksi yang paling utama adalah kenaikan kadar kolesterol total $(\geq 240 \mathrm{mg} / \mathrm{dl})$, kolesterol LDL ( $\geq 160 \mathrm{mg} / \mathrm{dl})$, kenaikan kadar trigliserida $(\geq 200 \mathrm{mg} / \mathrm{dl})$ serta penurunan kadar kolesterol HDL $(<40$ $\mathrm{mg} / \mathrm{dl}$ ) (Setiati et al., 2017). Profil lipid yang sering diperiksa antara lain kolesterol total, Low Density Lipoprotein (LDL), High Density Lipoprotein (HDL) serta trigliserida. LDL yang tinggi dapat menyebabkan aterosklerosis, sedangkan HDL mampu melindungi pembuluh darah terhadap aterosklerosis (antiaterogenik) (Mairina and Fitrina, 2018).

Mengetahui bahwa stroke merupakan penyebab kematian tertinggi di dunia dan juga di Indonesia, dan diperkirakan angka kejadian stroke akan terus mengalami lipid dalam plasma. Kelainan fraksi lipid peningkatan serta salah satu faktor risiko stroke erat kaitannya dengan kadar lipid, maka peneliti merasa tertarik untuk melakukan penelitian tentang perbedaan profil lipid pasien stroke iskemik dan stroke hemoragik di RSUD Meuraxa Banda Aceh periode Januari-Desember 2019.

\section{METODE}

Penelitian ini merupakan penelitian deskriptif analitik dengan desain penelitian Cross sectional. Pengambilan data dari rekam medik pasien stroke iskemik dan stroke hemoragik di RSUD Meuraxa Kota Banda Aceh periode Tahun 2019.

Jumlah sampel yang digunakan 56 pasien stroke yang terdiri dari 30 pasien stroke iskemik dan 26 pasien stroke hemoragik.

\section{HASIL}

\section{Tabel 1. Karakteristik pasien stroke iskemik dan hemoragik berdasarkan jenis kelamin dan kelompok usia}

\begin{tabular}{|c|c|c|c|}
\hline \multirow[b]{2}{*}{ Karakteristik } & \multicolumn{2}{|c|}{ Kategori Stroke } & \multirow[b]{2}{*}{ Total (\%) } \\
\hline & $\begin{array}{c}\text { Iskemik } \\
\text { N (\%) }\end{array}$ & $\begin{array}{c}\text { Hemoragik } \\
\text { N (\%) }\end{array}$ & \\
\hline \multicolumn{4}{|l|}{ Jenis Kelamin } \\
\hline Laki-Laki & $17(51,5)$ & $16(48,5)$ & $33(58,9)$ \\
\hline Perempuan & $13(56,5)$ & $10(43,5)$ & $23(41,1)$ \\
\hline \multicolumn{4}{|l|}{ Kelompok Usia } \\
\hline 50 - 55 tahun & $3(25,0)$ & $9(75,0)$ & $12(21,4 \%)$ \\
\hline $56-60$ tahun & $18(78,3)$ & $5(21,7)$ & $23(41,1 \%)$ \\
\hline $61-65$ tahun & $7(53,8)$ & $6(46,2)$ & $13(23,2 \%)$ \\
\hline 66 - 70 tahun & $2(25,0)$ & $6(75,0)$ & $8(14,3 \%)$ \\
\hline
\end{tabular}

Berdasarkan Tabel 1, jumlah sampel pasien penderita stroke yang dilibatkan dalam penelitian ini adalah sebanyak 56 orang, dengan rincian 30 orang dengan kategori stroke iskemik dan sisanya 26 orang dengan kategori stroke hemoragik. Jika dilihat berdasarkan kelompok usianya, maka diketahui bahwa pasien paling banyak berada pada kelompok usia antara 56 - 60 tahun yaitu sebanyak 23 orang $(41,1 \%)$ dengan perincian 18 orang (78,3\%) dengan stroke iskemik dan sisanya 5 orang $(21,7 \%)$ dengan stroke hemoragik. Sedangkan pasien yang paling sedikit berada pada kelompok usia antara 65-70 tahun yaitu hanya sebanyak 8 orang $(14,3 \%)$ yang didominasi oleh pasien dengan stroke hemoragik 6 orang $(75,0 \%)$. 
Tabel 2. Perbedaan Profil Lipid pada pasien stroke iskemik dan hemoragik.

\begin{tabular}{llccc}
\hline Profil Lipid & $\begin{array}{l}\text { Kelompok } \\
\text { Stroke }\end{array}$ & $\begin{array}{c}\text { N (\%) } \\
\text { Kolesterol Total }\end{array}$ & Rata-rata \pm SD & Kesimpulan \\
\hline & Hemoragik & $\begin{array}{c}(53,7) \\
(46,3)\end{array}$ & $193,6 \pm 44,6$ & $\begin{array}{c}\text { Kadar kolesterol } \\
\text { total berbeda }\end{array}$ \\
\hline HDL & 30 & $216,8 \pm 30,0$ & \\
& Iskemik & $(53,7)$ & $40,2 \pm 9,5$ & $\begin{array}{c}\text { Kadar HDL } \\
\text { berbeda }\end{array}$ \\
& Hemoragik & $(46,3)$ & $45,6 \pm 9,6$ & \\
\hline \multirow{2}{*}{ LDL } & Iskemik & $(53,7)$ & $131,9 \pm 30,8$ & Kadar LDL tidak \\
& Hemorbeda \\
& Iskemik & $(46,3)$ & $139,5 \pm 34,1$ & \\
\hline Trigliserida & $(53,7)$ & $132,3 \pm 76,7$ & Kadar Trigliserida \\
& Hemoragik & $(46,3)$ & $109,3 \pm 37,0$ & \\
& & & & \\
\hline
\end{tabular}

Tabel 2 menyajikan nilai ratarata dan standar deviasi masingmasing variabel kadar profil lipid pada kedua kelompok pasien stroke (iskemik dan hemoragik). Berdasarkan tabel 2 Rata-rata kadar kolestrol total, HDL, LDL dan trigliserida pada kelompok pasien stroke iskemik masing-masing adalah sebesar 193,6; 40,2; 131,9; dan 132,3 . Sedangkan kadar rata-rata kolestrol total, HDL, LDL dan dan trigliserida pada kelompok pasien stroke hemoragik masing-masing adalah sebesar 216,8; 45,6; 139,5; dan 109,3. Meskipun nilai rata-rata kadar kolesterol total, HDL, LDL dan trigliserida pada kedua kelompok pasien stroke terlihat sedikit berbeda, namun hasil pengujian Independent sample $t$ test maupun Mann-Whitney $U$ test menunjukkan bahwa hanya kadar

kadar LDL dan trigliserida pada kelompok pasien stroke iskemik tidak berbeda secara signifikan dengan kelompok pasien stroke hemoragik. Artinya, pasien dengan stroke iskemik memiliki kadar kolestrol total dan HDL kolestrol total dan HDL yang berbeda signifikan antara kelompok pasien iskemik dan hemoragik. Hal ini ditunjukkan dengan $p$-value pengujian yang lebih kecil dari 0,05. Sedangkan yang berbeda dengan pasien stroke hemoragik, sedangkan kadar LDL dan trigliserida pada kedua kelompok pasien stroke adalah sama.

\section{Hubungan antara profil lipid dengan kejadian stroke iskemik dan stroke hemoragik}

Hubungan antara profil lipid yang terdiri dari kadar kolesterol total, HDL, LDL dan trigliserida yang berskala rasio dengan kejadian stroke iskemik dan stroke hemoragik yang berskala nominal dikotomi (2 kategori) dapat dianalisis dengan Point Biserial Correlation yang merupakan kasus khusus dari korelasi Pearson's product moment.

Berdasarkan Tabel 3, diketahui bahwa nilai korelasi antara profil lipid kadar kolesterol total, HDL, LDL dan trigliserida dengan kategori stroke (iskemik dan hemoragik) masingmasing adalah sebesar 0,293; 0,275; 0,118 dan $-0,186$. Korelasi yang bernilai positif menunjukkan bahwa semakin tinggi kadar profil lipid, maka semakin besar kecenderungan pasien akan mengalami stroke hemoragik. Sedangkan korelasi yang bernilai negatif menunjukkan bahwa semakin tinggi kadar profil lipid, maka akan semakin rendah kecenderungan seorang pasien mengalami stroke 
hemoragik. Meskipun secara numerik profil lipid dan kejadian stroke memiliki nilai korelasi yang cukup besar, namun tidak semua nilai korelasi tersebut bermakna signifikan secara statistik. Nilai korelasi akan bermakna signifikan secara statistik apabila memiliki $p$ value pengujian yang lebih kecil dari pada 0,05. Dapat dilhat bahwa hanya kadar kolestrol total dan HDL yang berhubungan signifikan dengan kejadian stroke dengan nilai korelasi masing-masing sebesar 0,293 dan 0,275 . Hal ini menunjukkan bahwa semakin tinggi kadar kolesterol total dan HDL, maka semakin besar kemungkinan seorang pasien akan mengalami stroke hemoragik. Demikian juga sebaliknya, semakin rendah kadar kolesterol total dan $\mathrm{HDL}$, maka pasien cenderung akan mengalami stroke iskemik. Sedangkan kedua variabel profil lipid lainnya itu kadar LDL dan trigliserida tidak berhubungan secara signifikan dengan kejadian stroke iskemik dan hemoragik pada penelitian ini.

Tabel 3. Hubungan antara profil lipid dengan kejadian stroke iskemik dan stroke hemoragik

\begin{tabular}{lcc}
\hline \multicolumn{1}{c}{ Variabel } & $\begin{array}{c}\text { Koefisien } \\
\text { Korelasi }\end{array}$ & p-value \\
\hline Profil Lipid Kolesterol total - Kategori Stroke & 0,293 & 0,029 \\
Profil Lipid HDL - Kategori Stroke & 0,275 & 0,040 \\
Profil Lipid LDL - Kategori Stroke & 0,118 & 0,387 \\
Profil Lipid Trigliserida - Kategori Stroke & $-0,186$ & 0,169 \\
\hline
\end{tabular}

\section{PEMBAHASAN}

Dari hasil penelitian didapatkan jumlah pasien stroke lebih banyak lakilaki yaitu sebanyak 33 orang $(58,9 \%)$ sedangkan perempuan sebanyak 23 (41,1\%). Berdasarkan American Heart Association didapatkan bahwa serangan stroke pada laki-laki lebih banyak dibandingkan dengan perempuan dan ini dibuktikan dengan hasil penelitian yang menunjukan bahwa insidensi kejadian stroke lebih banyak pada laki-laki (Goldstein dkk, 2014). Hal ini berhubungan dengan hasil penelitian di Nigeria yang berjudul Gender Variation Risk Factors and Clinical Presentation of Acute Stroke, yang menemukan bahwa faktor risiko kebiasaan merokok dan riwayat mengkonsumsi alkohol ditemukan lebih dominan pada responden laki-laki dan berbeda signifikan dengan responden perempuan (Watila dkk., 2015) (Sofyan, 2015).

Menurut kelompok usia pasien stroke, didapatkan kelompok yang lebih banyak terkena stroke yaitu usia 56-60 tahun sebanyak 23 orang
$(41,1 \%)$. Hal ini sejalan dengan teori yang ada pada buku Ilmu Peyakit Dalam mengenai usia tersering yang mengalami stroke yaitu 55-64 tahun. Pasien stroke iskemik didominasi oleh kelompok umur 56-60 tahun sebanyak 18 orang (78,3\%). Sedangkan pasien dengan kelompok usia 50-56 tahun sebanyak 9 orang $(75,0 \%)$ mendominsasi angka kejadian stroke hemoragik.

Menurut hasil uji statistik terlihat bahwa perbedaan kadar kolesterol total dan HDL pada pasien stroke iskemik dan stroke hemoragik masing-masing bernilai $p=0,013$ dan $p=0,040$. Kolesterol total pada stroke hemoragik lebih tinggi dari pada stroke iskemik. Hasil penelitian ini berbeda dengan

penelitian yang dilakukan oleh Niriawati dkk yaitu kadar kolesterol total pada pasien stroke iskemik memiliki rerata $202 \pm 33,9 \mathrm{mg} / \mathrm{dl}$, lebih tinggi daripada pasien stroke hemoragik yang memiliki rerata $167,87 \pm 53,6 \mathrm{mg} / \mathrm{dl}$. Penelitian tersebut menunjukan bahwa kadar kolesterol total pada pasien stroke iskemik lebih tinggi daripada pasien 
stroke hemoragik (Aini, Pujarini and Nirlawati, 2016). Berdasarkan penelitian yang telah dilakukan, kadar HDL pada pasien stroke hemoragk lebih tinggi daripada stroke iskemik hasil ini sesuai dengan penelitian Zulhafis Mandala di RSUD DR. H. Abdul Moeloek Bandar Lampung bahwa kadar HDL pada pasien stroke iskemik lebih rendah dibandingkan stroke hemoragik dan juga sesuai dengan penelitian yang dilakukan oleh Agusti dkk yaitu kadar kolesterol HDL lebih rendah pada pasien stroke iskemik ditentukan sebanyak 40 pasien $(42,11 \%)$ dibandingkan stroke hemoragik sebanyak 8 pasien $(8,42 \%)$ (Agusti, 2014).

tidak madar LDL pada penelitian ini signifikan yaitu dengan nial $p=0,271$. Hal ini tidak sesuai dengan penelitian yang dilakukan Rizki Ismi (2015), yang mana pada penelitian tersebut didapatkan kadar LDL pada stroke hemoragik lebih rendah dibandingkan stroke iskemik (Arsyad, 2015). Pada penelitian ini juga kadar trigliserida tidak memiliki perbedaan signifikan yaitu dengan nilai $p=0,421$. Hal ini sesuai dengan penelitian yang dilakukan Zulhafis Mandala (2015) yaitu kadar trigliserida normal ataupun kadar trigliserida tinggi sama jumlahnya pada stroke iskemik dan stroke hemoragik (Di et al., 2015).

\section{KESIMPULAN}

Kolesterol total pada pasien stroke hemoragik lebih tinggi daripada stroke iskemik. Kadar HDL pada pasien stroke hemoragik lebih tinggi daripada stroke iskemik. Tidak terdapat perbedaan signifikan antara kadar LDL pada pasien stroke iskemik dan stroke hemoragik. Hanya kadar kolestrol total dan HDL yang berhubungan signifikan dengan kejadian stroke

\section{SARAN}

Penelitian selanjutnya diharapkan mengambil jumlah sampel penelitian yang lebih besar agar dapat melihat perbedaan yang lebih bermakna berkaitan dengan profil lipid pasien stroke iskemik dan stroke hemoragik.

Melihat angka kejadian baik stroke iskemik maupun hemoragik cukup tinggi, maka diharapkan diberikannya sosialisasi kepada masyarakat berkaitan dengan perbaikan gaya hidup dan faktor risikonya agar masyarakat lebih memahami dan tahu apa yang seharusnya dilakukan.

\section{DAFTAR PUSTAKA}

Agusti, N. I. (2014) 'Profil Rasio Kolesterol LDL dan HDL Pada Pasien Stroke di Bagian Saraf RSUD Arifin Achmad Provinsi Riau Periode Januari sampai Desember 2012', JOM FK Universitas Riau, 1(2), pp. 1-15.

Aini, Q. A., Pujarini, L. A. and Nirlawati, D. D. (2016) 'Perbedaan Kadar Kolesterol Total antara Penderita Stroke Iskemik dan Stroke Hemoragik', Journals UMS, 8(2), 8, pp. $1-5$.

Arsyad, R. I. (2015) Perbedaan Kadar LDL Pada Pasien Rawat Inap Stroke Iskemik dan Hemoragik di RSUP Dr. M. Djamil Padang. Universitas Andalas. Skripsi. Fakultas Kedokteran Universitas Andalas. Padang.

Badan Penelitian dan Pengembangan Kesehatan (2019) Kesehatan Indonesia Menghadapi Revolusi Industri 4.0. Jakarta.

Buis, J. (2017) Thirteen Chronic Disease, in Particular Stroke. Amsterdam: Thela.

Daniati and Erawati (2018) 'Hubungan Tekanan Darah dengan Kadar Kolesterol LDL (Low Density Lipoprotein) pada Penderita Penyakit Jantung Koroner di RSUP Dr. M. Djamil Padang', Jurnal Kesehatan Perintis, 5(2), pp. 153-158.

Darotin, R., Nurdiana and Nasution, T. H. (2017) 'Analisis Faktor Prediktor Mortalitas Stroke Hemoragik di Rumah Sakit

Daerah dr. Soebandi Jember', Nurseline Journal, 2(2), pp. 135-136.

$\mathrm{Di}, \mathrm{H}$. et al. (2015) 'Perbandingan Kadar Profil Lipid Darah Pada Stroke Iskemik dan Stroke 
Hemoragik di RSUD DR. $H$. Abdoel Moeloek Bandar Lampung 2014', 2(2), pp. 86-90.

Fauzah, U., Nurimba, N. and Tursina, A. (2019) 'Lipid Profile Picture of Ischemic Stroke and Bleeding Stroke Patients Young Age in RSAU Salamun Bandung March 2016-2018 Period', in Jurnal Unisba. Bandung: Departemen Neurologi Fakultas Kedokteran Unisba, pp. 586-594.

Ganong, W. F. (2014) Buku Ajar Fisiologi Kedokteran. Edited by D. Ramadhani. Jakarta: EGC.

Gerritsen, M. (2014) Cognitive Aftermath of Ischemic Stroke. Netherland: Netherlands Heart Foundation and Behavioral School of Cognitive Neurosciences (BNC).

Ghani, L., Mihardja, L. K. and Delima (2016) 'Faktor Risiko Dominan Penderita Stroke di Indonesia', Buletin Penelitian Kesehatan, 44(1), pp. 49-58.

Guyton, A. C. and Hall, J. E. (1997) Buku Ajar Fisiologi Kedokteran. Edisi ke-9. Edited by E. B. I. : I. Setiawan. Jakarta: EGC.

Hidayati, D. R. (2017) 'Hubungan Asupan Lemak dengan Kadar Trigliserida dan Indeks Massa Tubuh Sivitas Akademi UNY', Jurnal Prodi Biologi, 6(1), pp. 2531.

Humam, H. and Lisiswanti, R. (2015) 'Pengaruh Tomat (Solanum Lycopersicum) Terhadap Stroke', Majority, 4(9), pp. 88-89.

Irfan, M. (2015) Fisiologi Bagi Insan Stroke. Yogyakarta: Graha Ilmu.

Irwan (2018) Epidemiologi Penyakit Tidak Menular. Yogyakarta: Deepublish.

Kowalak and Jenifer P (2017) Buku Ajar Patofisiologi. Edited by Kowalak, Welsh, and Mayer. Jakarta: Penerbit Buku Kedokteran EGC.

Laulo, A., Tumboimbela, M. J. and Corry N Mahama (2016) 'Gambaran Profil Lipid pada Pasien Stroke Iskemik dan Stroke Hemoragik yang di Rawat Inap di Iriana $F$ RSUP Prof.DR.R.D. Kandou Manado Periode Juli-2015-Juni
Tahun

2016', Jurnal e-Clinic (eCl), 4(2), pp. 99-107.

Liang, T. H. and LIM, E. C.-H. (2015)

The Black Book of Clinical Examination. Edited by J. W. . Lim. Singapore: Mc Graw Hill Edication (Asia).

Listiyana, A. D. (2013) 'Obesitas Sentral dan Kolesterol Darah Total', Jurnal Kesehatan Masyarakat, 1(1), pp. 37-43. Available at: journal.unnes.ac.id.

Mairina and Fitrina, R. (2018) Gambaran Profil Lipid Pasien Stroke di Rumah Sakit Stroke Nasional Bukittinggi. Bukittinggi. Available at: yankes.kemkes.gp.id/read-gambaran-profil-lipid-pasienstroke-di-rumah-sakit-strokenasional-bukittinggi-5114.html.

Paciaroni, M. and Bogousslavsky, J. (2010) 'Primary and Secondary Prevention of Ischemic Stroke', European Neurology. Jakarta: Java Publisher, 63(5), pp. 267278. doi: $10.1159 / 000285183$.

Pinzon, R. (2012) Awas Stroke! Edited by Westriningsih. Yogyakarta: CV ANDI OFFSET (Penerbit ANDI).

Powers, W. J. et al. (2018) '2018 Guidelines for the Early Management of Patients With Acute Ischemic Stroke: A Guideline for Healthcare Professionals From the American Heart Association/American Stroke Association', Stroke, 49(3). doi: 10.1161/STR.0000000000000158

Puspita Ayu Ramadhani (2016) 'Hubungan Tingkat Stres, Asupan Natrium, dan Riwayat Makan dengan Kejadian Stroke', Jurnal e-Journal Unair, 2(3), pp. 104106.

Rachmat, C., Ticoalu, S. H. . and Wongkar, D. (2015) 'Pengaruh Senam Poco-Poco Terhadap Kadar Trigliserida Darah', Jurnal eBiomedik (e-Bm), 3(1), pp. 205210. 
Rahmawati, N. R. and Wati, A. P. (2016) 'Pengaruh Suplementasi Zinc Terhadap Keluaran Pasien Stroke Iskemia Akut', Jurnal Kedokteran Diponegoro, 5(4), pp. 13281338.

Sacco, R. L. et al. (2013) 'An Updated Definition of Stroke for the 21st Century', Stroke, 44(7), pp. 2064-2089. doi: 10.1161/STR.0b013e318296aeca.

Sanhia, A. M., Pangemanan, D. H. C. and Engka, J. N. A. (2015) 'Gambaran Kadar Kolesterol Low Density Lipoprotein (LDL) pada Masyarakat Pesisir Pantai', Jurnal e-Biomedik, 3(1), pp. 460-465. doi:

10.35790/ebm.3.1.2015.7425

Setiati, S. et al. (2017) Buku Ajar Ilmu Penyakit Dalam. Edited by Siti Setiati. Jakarta: Interna Publishing.

Siregar, R. N. I. (2015) 'The Effect of Eugenia Polyantha Extract on LDL Cholesterol', Jurnal Majority, 4(5), pp. 85-91.

Sofyan, A. M. (2015) 'Hubungan Umur, Jenis Kelamin, dan Hipertensi dengan Kejadian Stroke', Jurnal FK UHO, 3(2), pp. 24-25.

Syahrullah, R. R., Assa, Y. and Tiho, M. (2013) 'Gambaran Kadar High Density Lipoprotein Darah Pada Laki-laki Berusia 40-50 Tahun dengan Indeks Massa Tubuh $>23$ $\mathrm{kg} / \mathrm{m}^{2}$, Jurnal e-Biomedik (e$B m), 1(1)$, pp. 50-52.

Utama, H. (2013) Stroke Petunjuk Perawatan Pasien Pasca Stroke di Rumah. Jakarta: Balai Penerbit Fakultas Kedokteran Unviversitas Indonesia.

Wahyuddin and Arief W (2018) 'Pengaruh Pemberian PNF Terhadap Kekuatan Fungsi Prehension pada Pasien Stroke Hemoragik dan Non-Hemoragik', Jurnal Fisioterapi Indonesia, 8(1), pp. 88-90.

WHO (2014) Publishes Definitive Atlas on Global Heart Disease and Stroke Epidemic. Jenewa. Available at: http://www.who.int/mediacentre/ news/release/2014/pr68/en/index .html.

Yayasan Stroke Indonesia (2013) Jumlah Penderita Stroke Semakin Meningkat. Jakarta.

Yueniwati, Y. (2015) Deteksi Dini Stroke Iskemia dengan Pemeriksaan Ultrasonografii Vaskular dan Variasi Genetika. Edited by Ruri Erlangga. Malang: Universitas Brawijaya Press (UB Press).

Yunadi, Y. (2012) 'Intervensi pada Stroke Non-Hemoragik', Jurnal Kardiologi Indonesia, 31(3), pp. 155-159. Available at: ijconline.id/index.php/ijc/article/d ownload/126/129.

Zahara, F., Syafri, M. and Yerizel, E. (2015) 'Gambaran Profil Lipid pada Pasein Sindrom Koroner Akut di Rumah Sakit Khusus Jantung Sumatera Barat Tahun 2013-2015', Jurnal Fk Unand, 3(2), pp. 167-171. 